\title{
Trace Elements in Surface Water and Bottom Sediments in the Hyporheic Zone of Lake Wadąg, Poland
}

\author{
Marcin Siepak $^{1 *}$, Marek Marciniak², Mariusz Sojka ${ }^{3}$, Katarzyna Pietrewicz ${ }^{4}$ \\ 'Institute of Geology, Faculty of Geographical and Geological Sciences, Adam Mickiewicz University, Poznań, Poland \\ ${ }^{2}$ Institute of Physical Geography and Environmental Planning, Faculty of Geographical and Geological Sciences, \\ Adam Mickiewicz University, Poznań, Poland \\ ${ }^{3}$ Institute of Land Improvement, Environmental Development and Geodesy, Faculty of Environmental Engineering \\ and Spatial Management, Poznań University of Life Sciences, Poznań, Poland \\ ${ }^{4}$ Laboratory of Biological Spatial Information, Faculty of Biology, Adam Mickiewicz University in Poznan,
} Poznań, Poland

Received: 9 July 2018

Accepted: 4 June 2019

\begin{abstract}
Our paper presents the results of determining the contents of trace elements (TEs) in the surface water and bottom sediments of Lake Wadąg in Poland's Masurian Lakeland. The samples were collected in August 2015. Trace elements were determined in samples using inductively coupled plasma with mass detection (ICP-QQQ). To assess the chemical composition of surface water, use was made of multivariate statistical methods of data analysis: cluster analysis (CA) and principal component analysis (PCA). The use of pollution factors such as the geochemical index $\left(I_{g e o}\right)$, pollution index $(P I)$ and pollution load index (PLI) made it possible to distinguish groups of elements allowing for the analysis of spatial variation of bottom sediment in the studied area. Results showed increased concentrations of $\mathrm{Hg}$ among all bottom sediment sampling sites. The highest concentrations of determined elements occurred in sampling site No. 5. Surface water was characterized by $\mathrm{Hg}, \mathrm{Pb}$ and $\mathrm{Cu}$ concentrations higher than those of Pregoła's basin. Yet the comparison with average concentrations of these elements in Polish lakes revealed the increased concentration of $\mathrm{Hg}$.
\end{abstract}

Keywords: trace elements (TEs), mercury, surface water, bottom sediments, Wadąg Lake

\section{Introduction}

Changes in trace element (TE) concentrations in surface water may be induced by both natural and

*e-mail: Marcin.Siepak@amu.edu.pl

anthropogenic factors [1-3]. Lakes are the main place of deposition of TEs, transported by rivers and surface runoff from areas surrounding the reservoirs $[4,5]$. The crucial factor in changing the quality of surface water is TE mobility from bottom sediments of the lake, which in certain circumstances may be subject to re-release and migration to the water depth [6]. 
Studies of the chemical composition of bottom sediments provide additional information on quality changes in surface water in the past [6-8]. They may also provide reference data (background value), essential in determining the degree of lake contamination. They also allow for the classification of bottom sediments. The concentration and spatial variability of TEs in bottom sediments is an individual property of the reservoirs [9]. Varol et al. [10-11] indicate the highest metal concentrations in the vicinity of the entrance of streams and drains. In this part of the lake, there are good conditions for sedimentation of suspended particulate matter carrying large amounts of TEs. Sojka et al. [12] show that the TE concentrations in the bottom sediments of a reservoir were higher than in the river and were characterized by higher variability. Spatial variability of TE concentrations in the reservoir bottom sediments depends on morphometric parameters of the reservoir and water exchange time, which determine the sedimentation process. Lower water flow velocity leads to accumulate the TEs in sediment [13]. However, sediment resuspension altered the physical and chemical states of the water column, which in turn influenced metal behavior [14]. Griboff et al. [15] indicate that physicochemical changes in bottom sediments may lead to some TEs being more bioavailable. That depends on several factors such as: $\mathrm{pH}$, organic matter and redox conditions, among others [16].

During the analysis of water and bottom sediments in lake reservoirs in regard to TE content, the hyporheic zone should also be considered. The zone is the place where surface water and groundwater interact, and where processes of chemical composition formation may occur. The hyporheic zone was initially the object of ecological and biological research [17]. At present, many authors, including Unland et al. [18], analyze the phenomenon of interaction between surface and groundwater, stressing the importance of the hyporheic zone for drainage or supplying the surface water. Hydrochemical processes occurring in the exchange of surface and groundwater are also analyzed in detail $[19$, 20].

Lake Wadąg has been relatively little investigated in regard to TE content in water and bottom sediments. Most publications describe its sanitary state and biogenic balance [21]. The data on water chemistry come mainly from reports on the state of the environment in Warmińsko-Mazurskie Province. First studies of the direct catchment of Lake Wadagg investigated the protection zone of the Wadagg groundwater intake located in the southern part of the reservoir [22]. The exploitation of this intake started in 1964. In the beginning, its capacity was $12000 \mathrm{~m}^{3} / \mathrm{d}$. In the year 1970 , the supply of $40000 \mathrm{~m}^{3} / \mathrm{d}$ was approved. In following years the intake was gradually extended and in 1978 it reached the capacity of $20000 \mathrm{~m}^{3} / \mathrm{d}$. In the mid-1970s, excessive $\mathrm{Hg}$ concentrations were found for the first time in the water of Lake Wadąg and its tributaries. Hg was first found in the groundwater in 1979. In groundwater samples collected during the collective pumping of the well at the Wadąg intake (June-September 1980), Hg content of $14.7 \mu \mathrm{g} / \mathrm{L}$ was found [22]. The source of water contamination with $\mathrm{Hg}$ could be the mercurial seed dressing used in agriculture, sewage from the Polygraphic Plant or sewage from the Olsztyn Motor Tyres Factory. Hg was removed from drinking water in the treatment process during deferrization and manganese removal on sand filters. The large quantity of iron and manganese in water allowed for the sorption of $\mathrm{Hg}$ and its complex ions.

The main study aims were as follows: (1) to determine $\mathrm{TE}$ content, $\mathrm{Hg}$ in particular, in water and

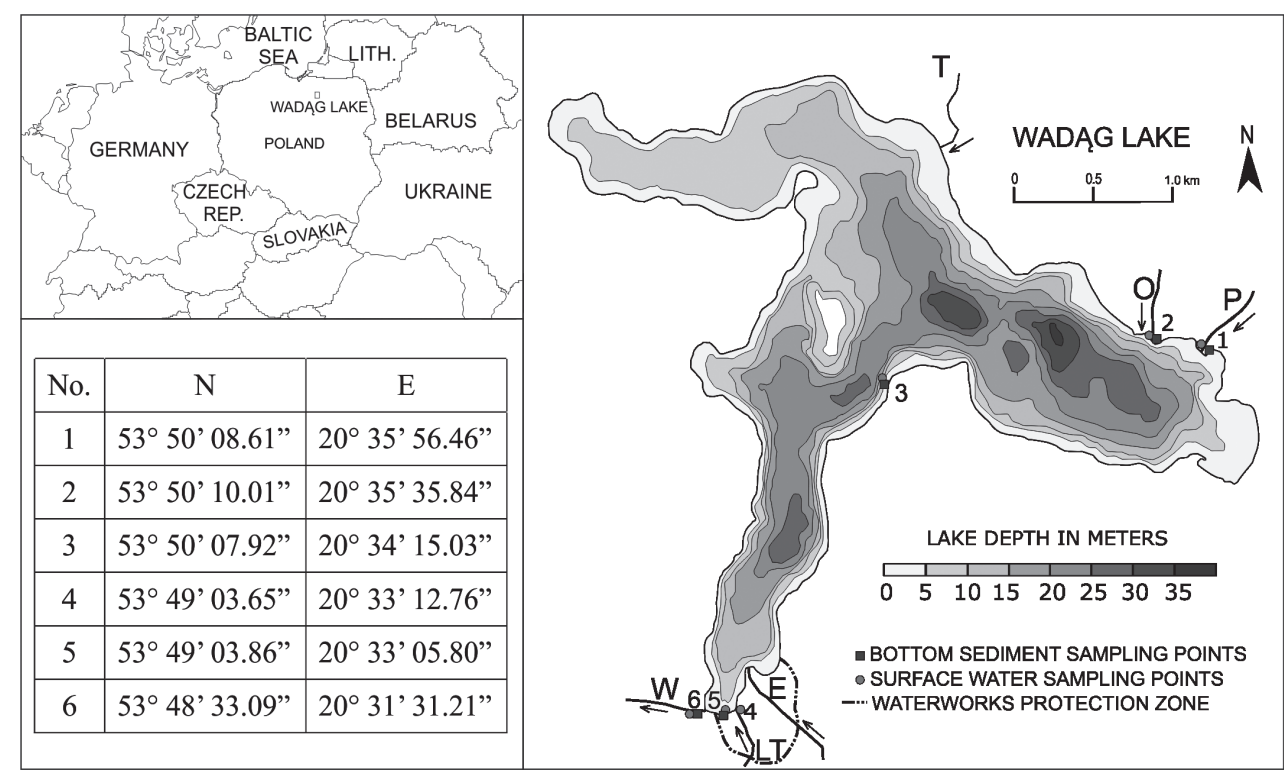

Fig. 1. Study area, on map: P - Pisa River, O - Orzechówka River, T - creek from Tuławka settlement, E - Elisabeth Canal, LT - creek from Lake Trackie, W - Wadąg River. 
bottom sediments of Lake Wadąg and its tributaries in the hyporheic zone. The studies were conducted 40 years after increased content of $\mathrm{Hg}$ was found in Lake Wadąg and its tributaries; (2) to determine the spatial distribution of studied elements in water and bottom sediments; (3) to assess the contamination degree of bottom sediments using the pollution index (PI), geoaccumulation index $\left(I_{\text {geo }}\right)$ and pollution load index (PLI).

\section{Materials and Methods}

\section{Study Area}

Lake Wadąg is located in Warmińsko-Mazurskie Province, about $7 \mathrm{~km}$ northeast from Olsztyn (Fig. 1). According to the Kondracki mesoregional typology [23], the lake is located in the central part of the Olsztyńskie Lakeland.

The reservoir is situated in the catchment area of the Łyna. It has a glacial origin, which represents the ribbon and dead-ice type of the lake. The surface area of Wadacg is 495 ha and its average depth according to Choiński [24] is $12.7 \mathrm{~m}$, and maximum depth is almost 3 times greater and amounts to $35.5 \mathrm{~m}$, which classifies the lake as the $30^{\text {th }}$ most voluminous in the Masuria Lakeland. Lake Wadąg is supplied by 5 watercourses: the Pisa, the Orzechówka, Elisabeth Canal, a creek from Tuławka settlement and a creek from Lake Trackie. The only watercourse flowing out of Lake Wadąg is the Wadąg River.

The anthropogenic impact is majorly related to agriculture, i.e., farmland and poultry farms situated in the northern and western part of the study area. The important factor is also the influence of industry - mainly its food processing branch, which is located in the area of the southern creek from Lake Trackie. The municipal landfill site, located in Łęgajny (about $4 \mathrm{~km}$ from the "Wadąg" groundwater intake) and closed in 2007, also has a significant impact on the natural environment, and primarily the water environment.

\section{Sample Collection and Preparation}

In August 2015 samples of water and bottom sediments were collected for physico-chemical analysis from Lake Wadąg and its three tributaries: the Pisa, the Orzechówka and a creek from Lake Trackie, as well as from the Wadag River flowing out of the lake (Fig. 1).

Measurements were taken directly in the field using a Multi 350i multi-functional measuring device made by the firm WTW (Weilheim, Germany) and included the temperature, $\mathrm{pH}$ reaction and electrolytic conductivity of the water. The $500 \mathrm{~mL}$ water samples were collected in Nalgene polyethylene bottles (HDPE) using a Toń 2 sampler (Mera Błonie, Gdańsk, Poland). The portions of the samples used for chemical analyses were acidified in situ. High-purity $65 \% \mathrm{HNO}_{3}$ (Merck, Darmstadt,
Germany) was used for trace element subsamples in an amount needed to obtain a $\mathrm{pH}<2$. After sampling, the samples were taken to the chemical laboratory in a mobile refrigerator at $4 \pm 2.5^{\circ} \mathrm{C}$. Adequate precautions were exercised to avoid contamination of water during sampling, transport, and handling.

Bottom sediment samples of $10 \mathrm{~cm}$ depth were collected by a Czapla-1 core sampler (Mera-Błonie, Gdańsk, Poland) into polyethylene (PE) containers. The sediment samples were dried at $105^{\circ} \mathrm{C}$ in a Binder FD 53 (Binder $\mathrm{GmbH}$, Germany). Dry samples were mineralized with aqua regia prepared from $\mathrm{HNO}_{3}: \mathrm{HCl}$ (1:3 v/v) by Merck (Merck, Darmstadt, Germany). The sample was mineralization at $95^{\circ} \mathrm{C} \pm 5^{\circ} \mathrm{C}$ in a Mars 5 Xpress microwave digestion system (CEM, Matthews, North Carolina, United States).

\section{Chemical Analysis}

Concentrations of $\mathrm{Al}, \mathrm{As}, \mathrm{Bi}, \mathrm{Cd}, \mathrm{Co}, \mathrm{Cr}, \mathrm{Cu}, \mathrm{Hg}, \mathrm{Li}$, $\mathrm{Ni}, \mathrm{Pb}, \mathrm{Sb}, \mathrm{Se}, \mathrm{Sr}, \mathrm{V}, \mathrm{Mo}, \mathrm{Zn}$, and $\mathrm{Rb}$ were determined by inductively coupled plasma mass spectrometry (ICPQQQ 8800 Triple Quad, Agilent Technologies, Japan). This instrument is equipped with a MicroMist nebulizer and a Peltier-cooled $\left(2^{\circ} \mathrm{C}\right)$ Scott-type spray chamber for sample introduction. This instrument contains an octopole-based collision/reaction cell located inbetween two quadrupole analyzers. It was operated in a gas mode, with $\mathrm{O}_{2}$ flowing at $0.3 \mathrm{~mL} / \mathrm{min}(30 \%)$ and He flowing at $5 \mathrm{~mL} / \mathrm{min}$. All parameters were manually optimized to achieve the best signal intensity and stability. MassHunter software for ICP-QQQ (Agilent Technologies, Japan) was used to control the instrument and to process the data [25]. The instrumental operating parameters are given in Table 1. The water samples were also analyzed for cations $\left(\mathrm{Ca}^{2+}\right.$ and $\left.\mathrm{Mg}^{2+}\right)$ and anions $\left(\mathrm{Cl}^{-}\right.$and $\left.\mathrm{SO}_{4}^{2-}\right)$ by employing a Metrohm ion

Table 1. ICP-QQQ operating conditions.

\begin{tabular}{|c|c|}
\hline Spectrometer & Agilent 8800 Triple Quad \\
\hline Nebulizer & Micromist \\
\hline Interface & Sampler and skimmer cones in Ni \\
\hline RF power & $1550 \mathrm{~W}$ \\
\hline RF matching & $1.80 \mathrm{~V}$ \\
\hline Plasma flow rate $(\mathrm{L} / \mathrm{min})$ & 15 \\
\hline Carrier gas flow $(\mathrm{L} / \mathrm{min})$ & 1.08 \\
\hline Nebulizer pump $(\mathrm{rps})$ & 0.3 \\
\hline S/C temp $\left({ }^{\circ} \mathrm{C}\right)$ & 2 \\
\hline Sample depth $(\mathrm{mm})$ & 8.0 \\
\hline Gas flow rate & \\
\hline & $\mathrm{He} 5.0(\mathrm{~mL} / \mathrm{min})$ \\
\hline & $\mathrm{O}_{2} 0.3(\mathrm{~mL} / \mathrm{min}) 30(\%)$ \\
\hline
\end{tabular}


chromatograph (IC), model 881 Compact IC Pro (Metrohm, Switzerland).

\section{Reagents and Certified Reference Material}

Determinations by ICP-QQQ technique were done using calibration curves obtained from the diluted stock multi-element standard $100 \mu \mathrm{g} / \mathrm{mL}$ (VHG Labs, Manchester, USA). A single-element model with the concentration of $10 \mu \mathrm{g} / \mathrm{mL}$ (VHG Labs, Manchester, USA) was used to obtain a calibration curve for $\mathrm{Hg}$. The reagents used were ultrapure, and the water was de-ionized to a resistivity of $18.2 \mathrm{M} \Omega \cdot \mathrm{cm}$ in a Direct-Q UV3 Ultrapure Water System apparatus (Millipore, France). Analytical quality control was verified by the analysis of certified reference materials, viz. SRM 1640a (National Institute of Standards and Technology, Gaithersburg, USA), SPS-SW2 (Spectrapure Standards As, Oslo, Norway) and SRM 2709 (National Institute of Standards and Technology, Gaithersburg, USA).

\section{Statistical Analysis}

The TE concentrations in water and bottom sediment samples before the statistical analysis using multivariate statistical techniques were log-transformed to obtain a normal distribution. In order to avoid misclassification due to wide differences in data dimensionality, the CA and PCA were applied to standardized data through z-scale transformation [10-11, 25-26].

Cluster analysis (CA) was applied to group samples into categories or clusters on the basis of similarities and dissimilarities in TE concentrations. CA was performed using squared Euclidean distances as a measure of similarity, and Ward's method to obtain dendrograms [27]. The CA was applied using Statistica 13.1.

The relationship between environmental factors and the analyzed groups of parameters (MEs and TEs) in water was determined by principal component analysis (PCA) with multiple scaling. Two environmental variables were applied during the analysis. The first environmental variable is a type of water in which rivers and lakes were distinguished, while the other is the influence of hydrological characteristics in the riverlake ecosystem on tributaries, the runoff, and the lake.

The PCA was preceded by detrended component analysis (DCA). The analysis of the gradient length of the first axis of DCA indicates that it was smaller than 3.0 SD. Glińska-Lewczuk [28] suggests that in such cases the principal component analysis (PCA) is the most appropriate method in analysis and interpretation of complex correlations and a synthetic presentation of the obtained results. The PCA and DCA analyses were performed with Canoco 5.0 software [29].

\section{Sediment Pollution Assessment}

$$
I_{\text {geo }}=\log _{2}\left(\frac{C_{n}}{1.5 B_{n}}\right)
$$

...where $C_{n}$ is the measured concentration of the element in the environment $[\mathrm{mg} / \mathrm{kg}]$ and $B_{n}$ is the geochemical background value in the sediment $[\mathrm{mg} / \mathrm{kg}]$.

Values of $I_{\text {geo }}$ were used to classify sediment samples into 7 purity classes: class $0\left(I_{\text {geo }} \leq 0\right)$ - uncontaminated, class $1 \quad\left(0<I_{\text {geo }} \leq 1\right)$ - uncontaminated to moderately contaminated, class $2 \quad\left(1<I_{\text {geo }} \leq 2\right)-$ moderately contaminated, class $3\left(2<I_{\text {geo }} \leq 3\right)-$ moderately to heavily contaminated, class $4\left(3<I_{\text {geo }} \leq 4\right)$ - heavily contaminated, class $5\left(4<I_{\text {geo }} \leq 5\right)$ - heavily to extremely contaminated, and class $6 \underset{\left(5<I_{\text {geo }}\right)}{ }$ - extremely contaminated [30,31].

Pollution index $(P I)$ is defined as the ratio of the metal concentration in the sample $\left(C_{n}\right)$ to the background value of the corresponding metal $\left(B_{n}\right)$ [32]. It is calculated as follows:

$$
P I_{n}=\frac{C_{n}}{B_{n}}
$$

The results allowed for the classification of sediment samples into four purity classes: class I $\left(P I_{n} \leq 1\right)-$ low contamination, class II $\left(1<P I_{n} \leq 3\right)$ - moderate contamination, class III $\left(3<\mathrm{PI}_{\mathrm{n}} \leq 6\right)-$ considerable contamination, class IV $\left(P I_{n}>6\right)-$ very high contamination.

Pollution load index $(P L I)$ is an experimental formula developed by Tomlinson et al. [32]:

$$
P L I=\left(C F_{a} C F_{b}\right)^{1 / n}
$$

...where $C F_{a}$ and $C F_{b}$ are ratios of elemental contents to their background values and $n$ is the number of elements.

The empirical index provides simple comparisons of site average heavy metal pollution. PLI was used to classify sediment samples into three purity classes: class I $\left(P L I_{n} \leq 0.5\right)$ - no significant pollution, class II $\left(0.5<P L I_{n} \leq 1\right)$ - sediment that requires further monitoring, and class III $\left(P L I_{n}>1\right)-$ sediment that requires immediate intervention to reduce pollution.

\section{Results and Discussion}

\section{Trace Elements in Water}

Field testing of water temperature, $\mathrm{pH}$, and electrical conductivity was undertaken at the time of sampling. For the most part, water temperatures ranged from $12.7^{\circ} \mathrm{C}$ to $22.8^{\circ} \mathrm{C}$, where the lowest temperature was found in the zone of supplying surface water with groundwater (Fig. 1, point 2). The $\mathrm{pH}$ of the studied water ranged from 7.11 to 8.58 . The high $\mathrm{pH}$ of the water may result in the reduction of TEs in water $[25,33]$. In the case of EC, the highest values were found in the zone of supplying the lake with groundwater - $605 \mu \mathrm{S} / \mathrm{cm}$ (point 2). In this site, in regard to basic macro components, the lowest concentrations of $\mathrm{Cl}^{-}$were found $(5.27 \mathrm{mg} / \mathrm{L})$, while the highest concentrations were 
Table 2. TE concentrations $(\mu \mathrm{g} / \mathrm{L})$ in surface water.

\begin{tabular}{|c|c|c|c|c|c|c|c|}
\hline \multirow{2}{*}{ Elements } & \multirow{2}{*}{ Unit } & \multicolumn{6}{|c|}{ Sampling site } \\
\hline & & 1 & 2 & 3 & 4 & 5 & 6 \\
\hline $\mathrm{Al}$ & \multirow{18}{*}{$\mu \mathrm{g} / \mathrm{L}$} & 0.61 & 0.50 & 0.18 & 0.67 & 0.20 & 0.13 \\
\hline As & & 1.18 & 0.32 & 0.91 & 0.94 & 0.93 & 0.91 \\
\hline $\mathrm{Bi}$ & & 0.004 & 0.005 & 0.010 & 0.036 & 0.002 & 0.001 \\
\hline $\mathrm{Cd}$ & & 0.006 & 0.009 & 0.006 & 0.013 & 0.013 & 0.020 \\
\hline Co & & 0.12 & 0.22 & 0.14 & 0.15 & 0.16 & 0.12 \\
\hline $\mathrm{Cr}$ & & 2.53 & 0.39 & 0.40 & 0.41 & 0.42 & 0.90 \\
\hline $\mathrm{Cu}$ & & 1.30 & 1.88 & 1.37 & 1.90 & 1.44 & 1.92 \\
\hline $\mathrm{Hg}$ & & 0.25 & 0.40 & 0.30 & 0.13 & 0.17 & 0.18 \\
\hline $\mathrm{Li}$ & & 5.39 & 9.00 & 5.05 & 5.15 & 5.04 & 5.03 \\
\hline $\mathrm{Ni}$ & & 0.81 & 1.18 & 0.86 & 1.18 & 0.90 & 1.22 \\
\hline $\mathrm{Pb}$ & & 0.80 & 0.34 & 1.71 & 1.95 & 0.95 & 1.50 \\
\hline $\mathrm{Sb}$ & & 0.12 & 0.18 & 0.11 & 0.22 & 0.14 & 0.13 \\
\hline $\mathrm{Se}$ & & 0.51 & 0.37 & 0.47 & 0.56 & 0.52 & 0.47 \\
\hline $\mathrm{Sr}$ & & 192.3 & 226.1 & 178.1 & 176.1 & 182.2 & 180.2 \\
\hline V & & 0.45 & 0.21 & 0.19 & 0.30 & 0.20 & 0.21 \\
\hline $\mathrm{Zn}$ & & 6.57 & 6.01 & 12.5 & 12.6 & 15.8 & 10.5 \\
\hline $\mathrm{Rb}$ & & 1.68 & 1.14 & 1.74 & 1.87 & 2.00 & 1.82 \\
\hline Mo & & 0.85 & 2.10 & 0.83 & 0.87 & 0.67 & 0.72 \\
\hline
\end{tabular}

found for $\mathrm{SO}_{4}^{2-}(25.4 \mathrm{mg} / \mathrm{L}), \mathrm{Ca}^{2+}(108.4 \mathrm{mg} / \mathrm{L})$ and $\mathrm{Mg}^{2+}$ $(17.7 \mathrm{mg} / \mathrm{L})$ in comparison with the other sampling sites.

Concentrations of TE in the water of Lake Wadąg are presented in Table 2. River water was characterized by higher average values of TEs compared to lake water. The average TEs with higher concentrations in Lake Wadąg were $\mathrm{Zn}, \mathrm{Rb}, \mathrm{Pb}, \mathrm{As}, \mathrm{U}$ and $\mathrm{Se}$. The differences were respectively $5.13 \mu \mathrm{g} / \mathrm{L}, 0.23 \mu \mathrm{g} / \mathrm{L}, 0.17 \mu \mathrm{g} / \mathrm{L}$, $0.08 \mu \mathrm{g} / \mathrm{L}, \quad 0.13 \mu \mathrm{g} / \mathrm{L}$ and $0.02 \mu \mathrm{g} / \mathrm{L}$. Maximum concentrations most often occurred in two samples located on river inflows 2 and 4, five times on each site. At the same time, minimum values occurred in sampling site 2 seven times. The high variability of TE concentrations in particular sampling sites is due to the fact that TEs flow into the lake water from different sources - not only through watercourses but also with surface runoffs and groundwater. Cluster analysis showed high variability in the content of TEs
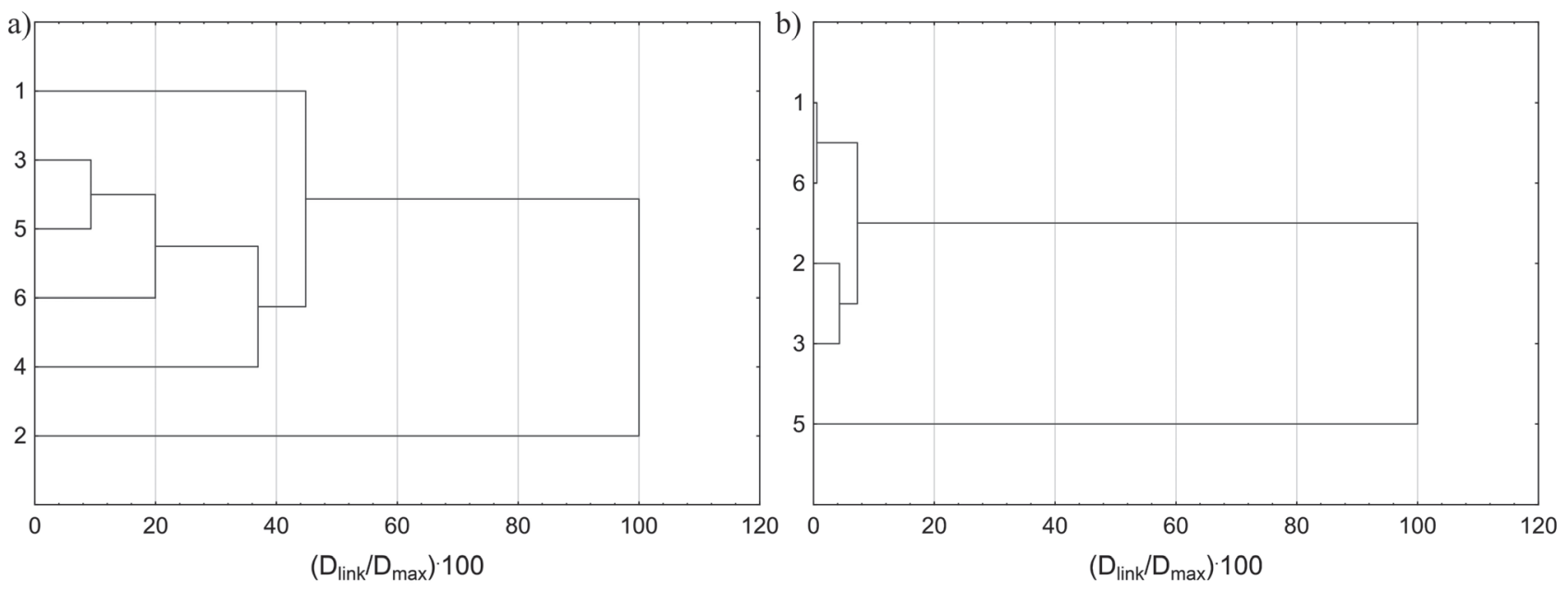

Fig. 2. Dendrogram showing clustering of sampling sites on the basis of TE concentrations in water a) and bottom sediments b). 

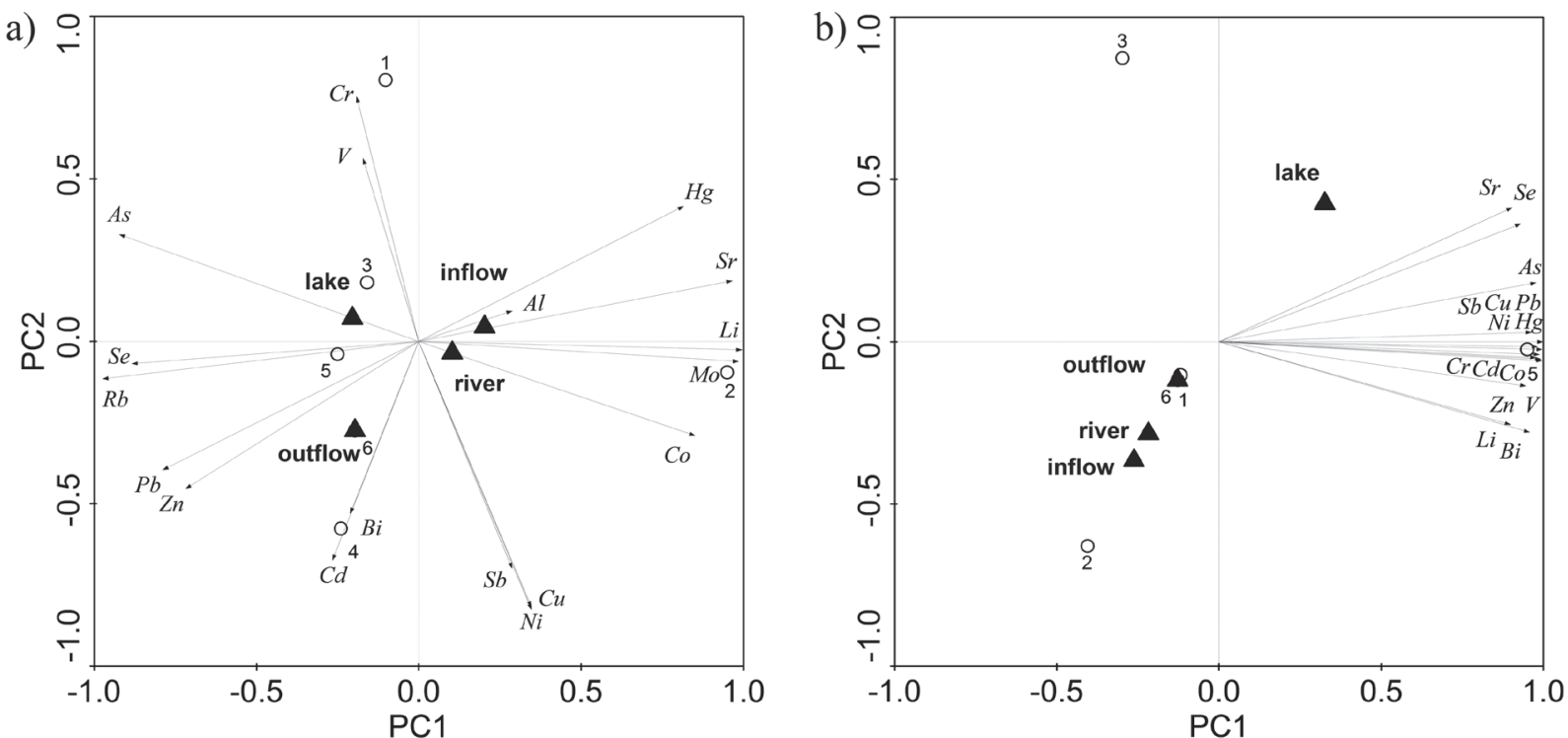

Fig. 3. Results of principal component analysis performed with the environmental variables and TE data in water a) and bottom sediments b).

in river and lake water. The highest similarity of TE concentrations was found in points 3 and 5, located within Lake Wadąg, most similar to which were the TE concentrations in the River Wadacg at point 6 (Fig. 2a). The highest variability of TE concentrations in relation to the other sampling sites was recorded in point 2 . The different chemical composition in sampling point 2 is associated with a shallow hyporheic zone. This is indicated by elevated values of elements such as $\mathrm{Sr}, \mathrm{Li}$, and Mo. On the other hand, the increased TE concentrations in the water of the creek from Lake Trackie probably result from the localization of this watercourse in the vicinity of the city of Olsztyn.

PCA analysis showed that the first main component was strongly positively correlated with $\mathrm{Li}, \mathrm{Mo}, \mathrm{Co}, \mathrm{Sr}$ and $\mathrm{Hg}$, and negatively with $\mathrm{Rb}, \mathrm{Se}, \mathrm{As}, \mathrm{Pb}$ and $\mathrm{Zn}$. The second main component was strongly positively correlated with $\mathrm{Cr}$ and $\mathrm{V}$ concentrations, and negatively with the concentrations of $\mathrm{Cu}, \mathrm{Ni}, \mathrm{Sb}$, and $\mathrm{Cd}$. The TE contents in creek water were characterized by high variability, the evidence of which is the large dispersion of points 1, 2 and 4 (Fig. 3a). The higher similarity was characteristic for the water of Lake Wadacg at points 3 and 5 , and the water running off the lake at point 6 . The accumulation of environmental variables in the first part of the coordinate system proves the lack of significant differences between TE concentrations in the water of lakes and rivers.

According to data obtained from the European Environmental Agency (EEA) [34], nearly all concentrations of selected elements in both the Pregoła basin and Polish lakes were higher than their corresponding average values in Lake Wadąg (Table 5). The surface water of Lake Wadąg was characterized by a slightly higher concentration of $\mathrm{Pb}$ and $\mathrm{Cu}$ compared to the Pregoła basin.
A comparison of the chosen 15 lakes of the Masurian Lakeland [35] reveals a minor increase of $\mathrm{Zn}$ concentration in the studied lake, yet it was lower than the mean value for both Pregoła basin and lakes of Poland [34]. Not only was the concentration of $\mathrm{Zn}$ lower, but also $\mathrm{Al}, \mathrm{As}, \mathrm{Cd}$ and $\mathrm{Ni}-$ as in Turkish lakes [36, 37]. Concentrations of those elements in Lake Wadąg were lowest compared to reference data [38] and Lakes of Bory Tucholskie [39].

Concentrations of $\mathrm{Hg}$ in surface water were higher in Lake Wadąg compared to both Pregoła basin and Polish lakes. The highest concentration of $\mathrm{Hg}$ was obtained in Orzechówka, which has a connection with groundwater. In 1986 Marciniak [22] analyzed groundwater in wells located in the southern part of Lake Wadacg. The results showed the extremely high concentration of $\mathrm{Hg}$ at $14.7 \mu \mathrm{g} / \mathrm{L}$.

\section{Trace Elements in Bottom Sediments}

The results of TE determinations in bottom sediment samples are presented in Table 3. The maximum values for all TEs occurred in sampling site 5, located in the southern part of Lake Wadąg, where they exceeded the average values several times. The minimum values of studied TEs were mainly recorded in point 2, where - as has been mentioned earlier - the surface water is supplied with groundwater.

The exceeded background values occurred in the case of 11 determinations. Worth noting is the occurrence of raised concentrations of elements in sampling site 5 . Nearly all elements whose values were higher than the background value of the corresponding element occurred at this sampling site. For example, the concentrations of $\mathrm{Cd}, \mathrm{Ni}, \mathrm{Sb}$, and $\mathrm{Sr}$ were over tenfold higher compared to the average concentrations 
Table 3. TE concentrations $(\mathrm{mg} / \mathrm{kg})$ in bottom sediments.

\begin{tabular}{|c|c|c|c|c|c|c|c|}
\hline \multirow{2}{*}{ Elements } & \multirow{2}{*}{ Unit } & \multirow{2}{*}{$\begin{array}{c}\text { Background } \\
\text { value* }^{*}\end{array}$} & \multicolumn{5}{|c|}{ Sampling site } \\
\hline & & & 1 & 2 & 3 & 5 & 6 \\
\hline As & \multirow{15}{*}{$\mathrm{mg} / \mathrm{kg}$} & 5 & 2.88 & 1.24 & 2.44 & 9.76 & 2.43 \\
\hline $\mathrm{Bi}$ & & - & 0.06 & 0.11 & 0.03 & 0.32 & 0.04 \\
\hline $\mathrm{Cd}$ & & 1 & 0.1 & 0.04 & 0.04 & 0.48 & 0.07 \\
\hline Co & & 5 & 1.21 & 0.62 & 0.7 & 3.94 & 1.20 \\
\hline $\mathrm{Cr}$ & & 10 & 4.20 & 2.51 & 2.68 & 28.1 & 4.92 \\
\hline $\mathrm{Cu}$ & & 10 & 3.42 & 1.84 & 2.31 & 19.1 & 3.08 \\
\hline $\mathrm{Hg}$ & & 0.15 & 0.19 & 0.18 & 0.18 & 0.35 & 0.19 \\
\hline $\mathrm{Li}$ & & - & 1.67 & 1.26 & 0.79 & 4.47 & 1.53 \\
\hline $\mathrm{Ni}$ & & 10 & 2.47 & 1.18 & 1.50 & 16.4 & 2.83 \\
\hline $\mathrm{Pb}$ & & 25 & 6.52 & 1.76 & 2.85 & 22.4 & 4.71 \\
\hline $\mathrm{Sb}$ & & - & 0.08 & 0.06 & 0.07 & 0.68 & 0.08 \\
\hline $\mathrm{Se}$ & & - & 7.89 & 4.32 & 11.0 & 33.8 & 8.00 \\
\hline $\mathrm{Sr}$ & & 40 & 16.9 & 7.96 & 33.8 & 151.3 & 16.3 \\
\hline V & & 10 & 4.26 & 3.58 & 3.78 & 12.4 & 5.68 \\
\hline $\mathrm{Zn}$ & & 100 & 21.5 & 9.40 & 9.20 & 76.1 & 23.8 \\
\hline
\end{tabular}

* Values after: Lis, Pasieczna [35], Values greater than background values are bolded

in other sites. The concentration of $\mathrm{Hg}$ is exceptional, and it exceeds the background value in all sites, with the maximum concentration at point 5 .

Cluster analysis allows for the classification of sampling sites into two groups (Fig. 2b). The first group included four points with lower concentrations of TEs, while the second group included point 5 . A point worth noting is that TE concentrations in bottom sediments of the Pisa and Wadąg rivers (sampling sites 1 and 6) were slightly more similar to sampling sites 2 and 3. The highest TE concentrations in the bottom sediments of Lake Wadąg in point 5 probably result from their flow with the water and suspended particulate matter from Lake Trackie. As shown earlier, TE concentrations in the water of the creek from Lake Trackie were slightly higher than in sampling sites 1, 3, 5 and 6. Sampling site 5 is probably located in the place where the substances carried by the creek from Lake Trackie are deposited. The influence of contamination on deposition may be exerted not only by the chemical composition of water flowing into the basin or the type of transported debris, but also by hydraulic conditions, including the time of water retention [7]. Cluster analysis showed a lower variability of $\mathrm{TE}$ concentrations in the bottom sediments than in the water.

The PCA analysis of bottom sediments showed that the first main component was strongly correlated with all the studied TEs. The second main component was moderately correlated with $\mathrm{Sr}$ and Se. The PCA analysis showed clearly higher TE concentrations in bottom sediments in sampling site 5 , while the lowest concentrations were found in point 2. From among the analyzed samples, the highest probability in relation to TEs was observed in sites 1 and 6. Average TE concentrations in bottom sediments of the lake were higher than in rivers. On the other hand, average TE concentrations in creeks were on a slightly lower level than in the bottom sediments of the River Wadąg (Fig. 3b).

The use of indexes $I_{g e o}, P I$ and $P L I$ allowed for determining the level of contamination of bottom sediments. Table 4 presents the calculation results of index $I_{\text {geo }}$ for selected elements in sampling sites. Up to $92 \%$ of $I_{\text {geo }}$ value is lower than 0 , which indicates the lack of sediment contamination. Almost $8 \%$ of the index value lies in the range between 0.13 and 1.33, which means that the sediments are uncontaminated or moderately contaminated. Such values occur in point 5 . Spatial distribution of the $I_{\text {geo }}$ index shows a relatively good condition of bottom sediments in the studied area.

Similarly to $I_{g e o}, P I$ determines the ratio of the current content of particular elements to their geochemical background [38]. Table 4 shows the results of $P I$ calculations. Most of the results $(83 \%$ - similarly to $I_{g e o}$ index) lie in the range of up to 1 and classify the content of elements as moderate contamination. More than $15 \%$ of the determined concentrations were classified as moderately contaminated, i.e., in the range 
Table 4. Geo-accumulation index (Igeo) and pollution index $(P I)$ of TEs in bottom sediment samples.

\begin{tabular}{|c|c|c|c|c|c|}
\hline \multirow{2}{*}{ Elements } & \multicolumn{5}{|c|}{ Sampling site } \\
\hline & 1 & 2 & 3 & 5 & 6 \\
\hline & \multicolumn{5}{|c|}{ Geo-accumulation index $\left(I_{g e o}\right)$} \\
\hline As & -1.38 & -2.60 & -1.62 & 0.38 & -1.63 \\
\hline $\mathrm{Cd}$ & -3.91 & -5.23 & -5.23 & -1.64 & -4.42 \\
\hline $\mathrm{Co}$ & -2.63 & -3.60 & -3.42 & -0.93 & -2.64 \\
\hline $\mathrm{Cr}$ & -1.84 & -2.58 & -2.48 & 0.91 & -1.61 \\
\hline $\mathrm{Cu}$ & -2.13 & -3.03 & -2.70 & 0.35 & -2.28 \\
\hline $\mathrm{Hg}$ & -0.24 & -0.32 & -0.32 & 0.64 & -0.24 \\
\hline $\mathrm{Ni}$ & -2.60 & -3.67 & -3.32 & 0.13 & -2.41 \\
\hline $\mathrm{Pb}$ & -2.52 & -4.41 & -3.72 & -0.74 & -2.99 \\
\hline $\mathrm{Sr}$ & -1.83 & -2.91 & -0.83 & 1.33 & -1.88 \\
\hline V & -1.82 & -2.07 & -1.99 & -0.27 & -1.40 \\
\hline $\mathrm{Zn}$ & -2.80 & -4.00 & -4.03 & -0.98 & -2.66 \\
\hline Th & -2.16 & -2.77 & -1.81 & -2.74 & -2.12 \\
\hline \multirow[t]{2}{*}{$\mathrm{U}$} & -2.91 & -3.58 & -2.04 & -1.35 & -2.94 \\
\hline & \multicolumn{5}{|c|}{ Pollution index $(P I)$} \\
\hline As & 0.58 & 0.25 & 0.49 & 1.95 & 0.49 \\
\hline $\mathrm{Cd}$ & 0.10 & 0.04 & 0.04 & 0.48 & 0.07 \\
\hline Co & 0.24 & 0.12 & 0.14 & 0.79 & 0.24 \\
\hline $\mathrm{Cr}$ & 0.42 & 0.25 & 0.27 & 2.81 & 0.49 \\
\hline $\mathrm{Cu}$ & 0.34 & 0.18 & 0.23 & 1.91 & 0.31 \\
\hline $\mathrm{Hg}$ & 1.27 & 1.20 & 1.20 & 2.33 & 1.27 \\
\hline $\mathrm{Ni}$ & 0.25 & 0.12 & 0.15 & 1.64 & 0.28 \\
\hline $\mathrm{Pb}$ & 0.26 & 0.07 & 0.11 & 0.90 & 0.19 \\
\hline $\mathrm{Sr}$ & 0.42 & 0.20 & 0.85 & 3.78 & 0.41 \\
\hline $\mathrm{V}$ & 0.43 & 0.36 & 0.38 & 1.24 & 0.57 \\
\hline $\mathrm{Zn}$ & 0.22 & 0.09 & 0.09 & 0.76 & 0.24 \\
\hline $\mathrm{Th}$ & 0.34 & 0.22 & 0.43 & 0.23 & 0.35 \\
\hline \multirow[t]{2}{*}{$\mathrm{U}$} & 0.20 & 0.13 & 0.37 & 0.59 & 0.20 \\
\hline & \multicolumn{5}{|c|}{ Pollution Load Index $(P L I)$} \\
\hline PLI & 0.35 & 0.18 & 0.25 & 1.52 & 0.22 \\
\hline
\end{tabular}

•background values after Lis, Pasieczna [35], Igeo values above 0 and, PI and PLI values above 1 are shown in bold

$1<P I_{n} \leq 3$. These values mainly occur in point 5 (about $60 \%$ ). The remaining $40 \%$ were found in the other sampling sites. However, they concern only Hg. The use of the index showed the contamination of bottom sediments with $\mathrm{Hg}$ in all sampling sites, and the increase of $\mathrm{Hg}$ concentration in regard of the geochemical background was from 20 to $130 \%$.

PLI allows for the determination of contamination in particular sampling sites. Most sampling sites are characterized by uncontaminated bottom sediments $(P L I<1)$. The least contaminated are the sediments in point 2 , with the inflow of groundwater. Only sampling site No. 5, located in the southern part of the lake, shows the contamination of bottom sediments of $P L I>1$. This may be related to the occurrence of $\mathrm{Hg}$ in the water of Wadąg intake in the year 1976 [22].

Compared to the bottom sediment of closely located Lake Sunia [40], the bottom sediment in Lake Wadąg is characterized by a lower concentration of $\mathrm{Cr}, \mathrm{Zn}$, and $\mathrm{Pb}$ (Table 5). The comparison of bottom sediments of Lake Symsar [41] and Lake Wadąg revealed higher concentrations of $\mathrm{Cu}, \mathrm{Ni}, \mathrm{Cd}, \mathrm{Zn}$ and $\mathrm{Pb}$ in Lake Symsar. Only the concentration of $\mathrm{Cr}$ was lower in Lake Symsar, while in Eğirdir Lake (Turkey) only the $\mathrm{Pb}$ [37]. According to the research conducted by Bojakowska and Gliwicz on 67 lakes of the Suwałki Lakeland [42], only the concentrations of $\mathrm{Hg}$ and $\mathrm{Cr}$ were lower in those lakes. Noteworthy is 
Table 5. Comparison of selected elements in surface waters and bottom sediments (average value).

\begin{tabular}{|c|c|c|c|c|c|c|c|c|c|c|}
\hline \multirow{3}{*}{ Location } & \multicolumn{9}{|c|}{ Elements } & \multirow{3}{*}{ Source } \\
\hline & $\mathrm{Al}$ & As & $\mathrm{Cd}$ & $\mathrm{Cr}$ & $\mathrm{Cu}$ & $\mathrm{Pb}$ & $\mathrm{Hg}$ & $\mathrm{Ni}$ & $\mathrm{Zn}$ & \\
\hline & \multicolumn{9}{|c|}{ Surface waters $(\mu \mathrm{g} / \mathrm{L})$} & \\
\hline Wadąg Lake & 0.19 & 0.92 & 0.009 & 0.41 & 1.41 & 1.33 & 0.24 & 0.88 & 14.2 & This paper \\
\hline The Pregoła Basin & 11.3 & 5.00 & 0.192 & 1.00 & 1.19 & 1.20 & 0.02 & 3.43 & 50.1 & {$[34]$} \\
\hline Lakes of Poland & 17.1 & 4.82 & 0.171 & 2.26 & 2.87 & 2.07 & 0.07 & 2.13 & 20.1 & {$[34]$} \\
\hline $\begin{array}{l}15 \text { Lakes of the Great Mas- } \\
\text { urian Lakes route }\end{array}$ & - & - & 1.10 & - & 3.10 & 2.60 & - & 4.90 & 12.9 & {$[35]$} \\
\hline Lakes of Bory Tucholskie & - & - & 1.40 & $<1.00$ & 3.10 & 22.1 & - & 2.13 & 11.6 & [39] \\
\hline Beyşehir Lake (Turkey) & 1610 & - & 2.00 & 6.00 & - & 5.70 & - & 4.90 & - & {$[36]$} \\
\hline \multirow[t]{2}{*}{$\begin{array}{l}\text { Eğirdir Lake } \\
\text { (Turkey) }\end{array}$} & - & 13.0 & - & - & 9.00 & 0.70 & - & 14.9 & 6.80 & {$[37]$} \\
\hline & \multicolumn{9}{|c|}{ Bottom sediments $(\mathrm{mg} / \mathrm{kg})$} & \\
\hline Wadąg Lake & 0.38 & 6.10 & 0.26 & 15.4 & 10.6 & 12.6 & 0.27 & 9.00 & 42.7 & This paper \\
\hline Sunia Lake & - & - & - & 16.2 & - & 36.7 & - & & 72.3 & {$[40]$} \\
\hline Symsar Lake & - & - & 0.36 & 8.68 & 14.6 & 45.5 & - & 26.0 & 110 & {$[41]$} \\
\hline 67 Suwałki region lakes & - & 8.00 & 0.90 & 12.0 & 12.0 & 34.0 & 0.09 & 9.00 & 82.0 & {$[42]$} \\
\hline $\begin{array}{l}\text { Eğirdir Lake } \\
\text { (Turkey) }\end{array}$ & - & 16.8 & - & - & 14.9 & 8.62 & - & 43.8 & 38.7 & [37] \\
\hline
\end{tabular}

- no data

the concentration of $\mathrm{Hg}$ in Lake Wadąg, which exceeds all of the concentrations in Table 5. That indicates the need for further research on the sources of $\mathrm{Hg}$ in water and bottom sediment in Lake Wadąg.

\section{Conclusions}

The results of the determination and analysis of surface water and bottom sediments permit the following conclusions:

1. The chemistry of water in Lake Wadacg is similar to other lakes located in the Pregoła catchment area, and only the $\mathrm{Hg}$ and $\mathrm{Pb}$ concentrations are higher in the studied reservoir. $\mathrm{Hg}$ content was much higher than its average concentration in the Polish lakes and requires more detailed research.

2. Trace element concentrations in the water of the studied lake and river system were highly diversified. The most similar in terms of TE concentrations was the water in Lake Wadąg and at the runoff in the Wadacg River. Due to the increased supply of groundwater, the surface water in point 2 was characterized by the increased content of TEs: $\mathrm{Sr}, \mathrm{Li}$, and Mo.

3. The increased TE concentrations in Lake Trackie creek are probably related to their flow from the area of the city of Olsztyn.

4. Most of the determinations of elements in bottom sediments using sample mineralization with aqua regia did not exceed the values of geochemical background. The increased concentrations mainly occurred in point 5 and regarded $\mathrm{Hg}, \mathrm{Sr}, \mathrm{Cr}$, and $\mathrm{Cu}$. $\mathrm{Hg}$ concentration was increased in all sampling sites in regard to the value of the geochemical background.

5. Factors such as $I_{\text {geo }}$ and $P I$ revealed contamination of bottom sediment with $\mathrm{As}, \mathrm{Cr}, \mathrm{Cu}, \mathrm{Hg}, \mathrm{Ni}$, and $\mathrm{Sr}$ in sampling site 5 . The $P I$ index indicates contamination with $\mathrm{Hg}$ not only in point 5 but also in the other sampling sites. The sediments in sampling site 2 are the least contaminated. For the PLI index, the contamination of sediments occurs at values PLI $>1$. The $P L I$ index reached the values from 0.18 in point 2 to 1.52 in point 5 , which indicates the sediment contamination in point 5. All the applied indexes indicated contamination in point 5 , which should be monitored.

6. TE concentrations in bottom sediments showed higher similarity than those found in water. The increased TE content in bottom sediments in Lake Wadąg (in the point located near the estuary of the creek from Lake Trackie) shows TE deposition related to the carried debris.

\section{Acknowledgements}

This research was funded by the following projects: the National Science Centre, No. 2015/17/8/ST10/01833, titled "Conditions of the daily fluctuations in the levels 
of water in rivers and springs taking into account the influence of hyporheic zone," and the Ministry of Science and Higher Education, No. 215862/E-336/ SPUB/2017/1

\section{Conflict of Interest}

The authors declare no conflict of interest.

\section{References}

1. MAO D., CHERKAUER K.A. Impacts of land-use change on hydrologic responses in the Great Lakes region. J. Hydrol., 374 (1-2), 71, 2009.

2. SOJA G., ZÜGER J., KNOFLACHER M., KINNER P., SOJA A. M. Climate impacts on water balance of a shallow steppe lake in Eastern Austria (Lake Neusiedl). J. Hydrol., 480, 115, 2013.

3. CIĄŻELA J., SIEPAK M., WÓJTOWICZ P., Tracking heavy metal contamination in a complex river-oxbow lake system: Middle Odra Valley, Germany/Poland. Sci. Total Environ. 616-617, 996, 2018.

4. WALLING D.E. The impact of global change on erosion and sediment transport by rivers: current progress and future challenges. UNESCO, 2009.

5. SOJKA M., SIEPAK M., GNOJSKA E. Assessment of heavy metal concentration in bottom sediments of Stare Miasto Pre-dam Reservoir on the Powa River. Rocz. Ochr. Sr., 15 (2), 1916, 2013.

6. GUOQIANG W., YINGLAN A., HONG J., QING F., BINGHUI Z. Modeling the source contribution of heavy metals in surficial sediment and analysis of their historical changes in the vertical sediments of a drinking water reservoir. J. Hydrol., 520, 37, 2015.

7. HOSONO T., SU C.C., SIRINGAN F., AMANO A., ONODERA S. Effects of environmental regulations on heavy metal pollution decline in core sediments from Manila Bay. Mar. Pollut. Bull., 60 (5), 780, 2010.

8. HARIKUMAR P.S., NASIR U.P. Ecotoxicological impact assessment of heavy metals in core sediments of a tropical estuary. Ecotoxicol. Environ. Saf., 73 (7), 1742, 2010.

9. SMAL H., LIGEZZA S., WÓJCIKOWSKA-KAPUSTA A., BARAN S., URBAN D., OBROŚLAK R., PAWŁOWSKI A. Spatial distribution and risk assessment of heavy metals in bottom sediments of two small dam reservoirs. Arch. Environ. Prot., 41 (4), 67, 2015.

10. VAROL M., SSN B. Assessment of surface water quality using multivariate statistical techniques: A case study of Behrimaz Stream, Turkey. Environ. Monit. Assess., 159 (1-4), 543, 2009.

11. VAROL M., GOKOT B., BEKLEYEN A., SEN B. Water quality assessment and apportionment of pollution sources of Tigris River (Turkey) using multivariate statistical techniques - a case study. River Res. Appl., 28 (9), 1428, 2012.

12. SOJKA M., SIEPAK M., JASKUŁA J., WICHERDYSARZ J. The heavy metals transport in river - reservoir system: A case study of Stare Miasto Reservoir and Powa River. Pol. J. Environ. Stud., 27 (4), 1725, 2018.

13. RAJESHKUMAR S., LIU Y., ZHANG X., RAVIKUMAR B., BAI G., LI X. Studies on seasonal pollution of heavy metals in water, sediment, fish and oyster from the
Meiliang Bay of Taihu Lake in China. Chemosphere, 191, 626, 2018

14. ZHENG S., WANG P., WANG C., HOU J., QIAN J. Distribution of metals in water and suspended particulate matter during the resuspension processes in Taihu Lake sediment, China. Quatern. Int., 286, 94, 2013.

15. GRIBOFF J., HORACEK M., WUNDERLIN D.A., MONFERRAN M.V. Bioaccumulation and trophic transfer of metals, As and Se through a freshwater food web affected by antrophic pollution in Córdoba, Argentina. Ecotox. Environ. Safe., 148, 275, 2018.

16. NIKINMAA M. Factors affecting the bioavailability of chemicals. Aquat. Toxicol., 65, 2014.

17. GIBERT J. Groundwater ecology from the perspective of environmental sustainability. In: Proc. First Int. Conf. Groundw. Ecol. 3, 1992.

18. UNLAND N. P., CARTWRIGHT I., ANDERSEN M. S., RAU G. C., REED J., GILFEDDER B. S., ATKINSON A.P., HOFMANN H. Investigating the spatio - temporal variability in groundwater and surface water interactions: a multi - technique approach. Hydrol. Earth Syst. Sci., 17, 3437, 2013

19. JAWORSKA-SZULC B., PRUSZKOWSKA-CACERES M., PRZEWŁÓCKA M. Analysis of surface water and groundwater contact based on the research on their quality in the young glacial area of the Kaszubskie Lakeland. Geological Review - Przegląd Geol., 62 (4), 204, 2014.

20. MAZUREK M., KRUSZYK R., SZPIKOWSKA G. Transformation of chemical composition of groundwater in source niches in young glacial areas (The Parsęta basin) Monogr. Kom. Gospod. Wodnej PAN, 20 (2), 355, 2014.

21. LOSSOW K., GAWRONSKA H. Extermal imput to lake Wadag - effective and estimate loadings. Pol. J. Environ. Stud., 7 (2), 95, 1998.

22. MARCINIAK M., STELMACH M., URBANIAK H. Application of analogue modeling in determination of protection zones of the "Wadąg" intake near Olsztyn. In: Providing water to cities and villages (pages 28-35). PZiTS O/Poznań, 1982.

23. KONDRACKI J. Regional geography of Poland. PWN, 2011.

24. CHOIŃSKI A. Lakes of Poland catalogue. PWN, 2013.

25. SIEPAK M., SOJKA M. Application of multivariate statistical approach to identify trace elements sources in surface waters: a case study of Kowalskie and Stare Miasto reservoirs, Poland. Environ. Monit. Assess., 189, 364, 2017.

26. SOJKA M., SIEPAK M., ZIOŁA A., FRANKOWSKI M., MURAT-BŁAŻEJEWSKA S., SIEPAK J. Application of multivariate statistical techniques to evaluation of water quality in the Mała Wełna River (Western Poland). Environ. Monit. Assess., 147 (1-3), 159, 2008.

27. LI S., ZHANG Q. Spatial characterization of dissolved trace elements and heavy metals in the upper Han River (China) using multivariate statistical techniques. J. Hazard. Mater., 176 (1-3), 579, 2010.

28. GLIŃSKA-LEWCZUK K., BURANDT P., KUJAWA R., KOBUS S., OBOLEWSKI K., DUNALSKA J., GRABOWSKA M., LEW S., CHORMAŃSKI J. Environmental factors structuring fish communities in floodplain lakes of the undisturbed system of the Biebrza River. Water, 8 (4), 146, 2016

29. BRAAK C., SMILAUER P. Canoco reference manual and user's guide to Canoco for Windows. Software for Canonical Community Ordination (version 4.5), 2002. 
30. BOJAKOWSKA I., SOKOŁOWSKA G. Geochemical classes of water sediment cleanliness. Prz. Geol. Geological Review, 46 (1), 49, 1998.

31. WEI B., YANG L. A review of heavy metal contaminations in urban soils, urban road dusts and agricultural soils from China. Microchem. J., 94 (2), 99, 2010.

32. TOMLINSON D.L., WILSON J.G., HARRIS C.R., JEFFREY D.W. Problems in the assessment of heavymetal levels in estuaries and the formation of a pollution index. Helgol. Mar. Res., 33, 566, 1980.

33. WASIM AKTAR M., PARAMASIVAM M., GANGULY M., PURKAIT S., SENGUPTA D. Assessment and occurrence of various heavy metals in surface water of Ganga river around Kolkata: a study for toxicity and ecological impact. Environ. Monit. Assess., 160 (1-4), 207, 2010.

34. EUROPEAN ENVIRONMENT AGENCY. Waterbase water quality, 2016.

35. KACAPER K., KOWALSKA-GÓRALSKA M., SENZE M. Selected indexes of surface water quality in the littoral of the lakes on the Great Masurian Lakes tourist route. ECO-DOC, 245, 2012.

36. TEKIN-ÖZAN S., KIR I. Concentrations of some heavy metals in tench (Tinea tinea L., 1758), its endoparasite (Ligula intestinalis L., 1758), sediment and water in
Beyșehir Lake, Turkey. Pol. J. Environ. Stud., 17 (4), 597, 2008.

37. ŞENER Ş., DAVRAZ A., KARAGÜZEL R. Assessment of trace metal contents in water and bottom sediments from Eğirdir Lake, Turkey. Environ. Earth Sci., 71 (6), 2807, 2014.

38. LIS J., PASIECZNA A. Geochemical atlas of Poland. Publishing house PIG, 1995.

39. GWOŹDZIŃSKI K., MAZUR J., PIENIĄŻEK A. Concentrations of metals in water of unmonitored lakes near a Landscape Park. Pol. J. Environ. Stud., 23 (4), 1317, 2014.

40. SIDORUK M., POTASZNIK A. Spatial distribution of lead, zinc and chromium in the bottom deposits of Lake Sunia. Ecol. Chem. Eng. S, 22 (2), 243, 2016.

41. KURIATA-POTASZNIK A., SZYMCZYK S. S., SKWIERAWSKI A., GLINSKA-LEWCZUK K., CYMES I., GLIŃSKA-LEWCZUK K., CYMES I. Heavy metal contamination in the surface layer of bottom sediments in a flow-through lake: A case study of Lake Symsar in Northern Poland. Water (Switzerland), 8 (8), 358, 2016.

42. BOJAKOWSKA I., GLIWICZ T. Trace elements in the sediments of the lakes in the Suwałki Region. Pr. i Stud. Geogr., 44, 57, 2009. 
